\title{
Traces of old and new center-periphery dynamics in language-in-education policy and practice
}

\author{
Insights from a linguistic ethnographic study \\ in Timor-Leste
}

Ildegrada Da Costa Cabral \& Marilyn Martin-Jones

University of Birmingham, England

This article reveals how center-periphery relations have unfolded, over time, in language policy processes in one nation - Timor-Leste - on the global periphery. We take a longue durée perspective on the language policy processes at work in this historical context, showing how different regimes of language were imposed, in the past, by colonisers from distant centers - in Portugal and then in Java, Indonesia. Then, turning to the post-independence period, we show how a new order of indexicality, forged within the Resistance to the Indonesian occupation, formed the basis for current language policy in Timor-Leste, with Portuguese and Tetum as co-official languages. We also demonstrate that this agentive policy move, from the global periphery, oriented Timor-Leste to new and more complex center-periphery relations, to a 'lusophone' world, with Portugal and Brazil as key players. Our account of contemporary policy discourses in Timor-Leste, and of the consequences for language policy implementation, on different scales (national and local), draws on recent research of an ethnographic and multiscalar nature conducted in Timor-Leste (Da Costa Cabral, 2015).

Keywords: center-periphery dynamics; language ideologies; language policy; multilingual

\section{Introduction}

In this article, our focus is on language-in-education policy processes (past and present) in Timor-Leste, a relatively new nation-state in South East Asia, which became independent in 2002. We draw on recent research, of an ethnographic and multi-scalar nature, conducted by Ildegrada Da Costa Cabral in Dili, the capital of Timor-Leste (Da Costa Cabral, 2015). The case of Timor-Leste is of particular 
interest for two reasons: firstly, because of the major political changes that have taken place in this nation's history, taking it from four and a half centuries of Portuguese colonial rule (circa 1514 to 1975) to military invasion and twenty four years of occupation by Indonesia (the neighbouring country), to sustained Timorese resistance to occupation, to a UN-sponsored referendum and, eventually, to independence. These were changes that generated major shifts in languagein-education policy. Secondly, because, on independence in 2002, the national language policy was created in very different global conditions from those in place for other nations that gained their independence in the mid-twentieth century. Timor-Leste's national language policy was developed within the multi-polar world of the twenty first century. Portuguese was designated as a national, official language, along with Tetum, the language that is most widely spoken, often as a second language.

The starting point for the research presented in this article is with epistemological developments in three closely related fields of socio/applied linguistics: (1) Critical historical research on language policy; (2) research in the ethnography of language policy, and (3) studies in the sociolinguistic ethnography of interaction in multilingual classrooms. There has been increasing convergence in theory and method in these three fields, as scholars have adopted critical and poststructuralist perspectives on language in social life, and as they have shifted towards multi-scalar forms of enquiry. (A detailed account of these shifts is provided in Martin-Jones \& Da Costa Cabral, 2018.) For well over a decade now, researchers have demonstrated the advantages that accrue from multi-scalar investigation of policy-related language practices and ideologies, from local to national, focusing on social actors who are positioned, in different ways (e.g. Blommaert, 2007; Hornberger \& Johnson, 2007; McCarty, 2011; Johnson, 2009, 2013; Hult, 2015; Tollefson \& Pérez-Milans, forthcoming).

However, in our view, there has been insufficient attention in language policy research to the interrogation of processes at work on a global scale that are shaping language policy developments. In this article, we make the case for the adoption of a center-periphery lens on the language policy processes unfolding on this scale. We argue that a center-periphery lens offers a promising new perspective on these processes: one that is well suited to the study of change over time, while taking account of historical contingency; and, one that serves as a valuable means of building an understanding of the complex, contemporary conditions in which nation-states, on the periphery of the global economy, are developing national language-in-education policies.

Our argument is based on the assumption that the construction of centerperiphery relations, at particular historical moments, is underpinned by political and economic processes, and that they are also constructed discursively, with 
language and culture being used as emblems of nation-states or of supranational organisations. Taking this ontological position implies a particular 'way of looking' and a particular analytic approach. As Pietikainen et al. (2016: 194-195), have put it:

The analytic emphasis ...falls on center-periphery discourses which encompass how spaces, groups, practices, culture and language are constructed as being more or less central or peripheral at particular moments and how these polarised constructions acquire value in some conditions while being challenged in others [The use of italics is that of the original authors].

To demonstrate the value of tracking changes in center-periphery relations over time, the next section of this article provides a historical analysis of the political, discursive and ideological processes that have shaped the development of language policy in Timor-Leste. Following Franchescini (2013), we adopt a longue durée perspective, starting with the Portuguese colonial era.

The third section of the article provides an account of the design and conduct of the wider ethnographic study by Ildegrada Da Costa Cabral that we are drawing on. Then, in sections four and five, we present and analyse examples of textual, discursive and ethnographic data. Section four focuses on discourses about the current national language-in-education policy in Timor-Leste. These are discourses that surfaced during the course of interviews with two elite social actors. Section five presents an analysis of an extract of multilingual classroom discourse, from a teaching/learning episode observed in a local school in Dili. The extract illustrates the ways in which a primary school teacher and her students drew on different linguistic and cultural resources, as they endeavoured to make sense of the language and content of a school text in Portuguese - a text that had been designed and produced in Portugal. In the sixth and final section, we make brief concluding remarks.

\section{Changing center-periphery relations, changing discourses about language and changes in language-in-education policy and practice}

\section{The eastern region of the island of Timor: Imposition of a colonial order (1514-1974)}

The first three centuries of Portuguese colonial rule saw the establishment of a military presence, the development of an extractive economy (e.g. the export of sandalwood) and the arrival of various groups of Catholic missionaries. Unlike the Portuguese colonies in Africa (e.g. Angola, Guinea Bissau and Mozambique), there was no significant move towards the development of a settler economy. 
In 1769, the capital of the Portuguese colony was established in Dili. From then onward, the Tetum language began to be used as a lingua franca. It had already been used by colonial missionaries in some regions as a language for evangelisation (Hayek, 2000). Over time, in the new contact zone of Dili, where people of different language backgrounds mingled, a new variety of Tetum emerged - a variety that incorporated linguistic resources from Portuguese (e.g. lexis and syntax). In the early twentieth century, this came to be known as Tetum Praça and is today known locally as Tetum Dili.

In the late nineteenth century, the Portuguese colonialists began to move towards establishing greater control over the whole of this peripheral colony, moving into the interior from coastal outposts. These moves from the center led to successive uprisings. Colonial domination over the whole of the eastern region of the island of Timor was finally accomplished militarily by 1912 (Taylor, 1999).

From this point onwards, the Portuguese imposed a strictly regulated colonial order which was undergirded by discourses about language, about tradition and modernity, and about citizenship which were to become increasingly authoritarian over the next fifty years or so. In the early twentieth century, a new system for defining colonial citizenship was introduced - the assimilado system. It lasted until 1974. One of the conditions for achieving assimilado status was evidence of an ability to speak, read and write Portuguese. Since educational provision was limited, only the members of a small elite in the urban areas of the colony were able to meet these conditions and embrace a Portuguese life-style (Lemos Pires, 1991; Hayek, 2002). In 1930, the Acto Colonial reinforced this definition of citizenship. Then, in 1933, it was incorporated into the Constitution of the Estado Novo, under the dictatorship of António de Oliveira Salazar. The aim of the Act was stated as being to "bring indigenous people into western civilisation and the Portuguese nation" (Vale de Almeida, 2008: 3).

Through this Act and through the new Constitution of the Estado Novo, ties between the colonial state and the Catholic Church were strengthened. The Church in the colonies was given protection by the government in Lisbon. This commitment was ratified in a Concordat signed with the Vatican in 1940. Since most education continued to be provided by the Church, Portuguese-medium education was underpinned by moral and religious discourses. Portuguese was now represented as the language of a modern state and of metropolitan and Christian values, while local languages were represented as traditional and associated with animist beliefs.

During the final years of colonial rule, all opposition was stifled, in Portugal and in all the colonies. The activities of the secret police, under the regimes of Salazar and Marcelo Caetano are now well documented. The intransigence of these 
regimes and the colonial wars in Africa finally brought the Caetano regime to an end in the Carnation Revolution of 1974 (MacQueen, 1997).

In 1974, a process of decolonisation was initiated in all colonies. In the eastern region of Timor, political parties were formed in preparation for elections. The two main parties were FRETILIN (Frente Revolucionária do Timor-Leste Independente - Revolutionary Front for an Independent East-Timor), and UDT (União Democrática Timorense - the East Timorese Democratic Union). Most of the members of the leadership of these two parties had received a Portuguesemedium education. A handful had also had access to university education in Lisbon. FRETILIN was the pro-independence party and UDT called for continued alliance with Portugal. Due to increasing tension between these two political parties, a brief civil war broke out in 1975 and the Portuguese colonial administration withdrew from the territory (Taylor, 1999). Eventually, FRETILIN gained the upper hand and the UDT leadership withdrew to Indonesia. FRETILIN then made a unilateral declaration of independence on November 28, 1975, naming the new nation Timor-Leste.

\section{The Indonesian occupation, the imposition of a new center and the East} Timorese Resistance (1975-1999)

In 1974, in the light of political changes in Portugal, the military government in Indonesia began preparing the ground for an invasion from West Timor. The final, full-scale invasion came on December 7, 1975 (Taylor, 1999). The imposition of power from the new center was achieved with brutal force, leading to massive loss of life and imprisonment. Power was also imposed through a new system of bureaucracy, regulation and surveillance. After the invasion, the eastern region of Timor remained closed until the mid-1980s (Nixon, 2012).

The region was re-named Timor Timur (East Timor) and was incorporated into the Republic of Indonesia as its '27th Province.' A new and extended system of education was created, with the Indonesian language as the sole medium of instruction. As Errington (1998) has noted, the obligatory use of Indonesian in education and in other domains of social life was an integral part of the modernist national development project (Pembangunan Nasional) of the government of the time. The aim of the Indonesian authorities was to achieve rapid political, cultural and linguistic transformation of the region (Hayek, 2002).

The harsh regulatory practices of the Indonesian occupation and the monolingual ideology underpinning all aspects of public life did not go uncontested. Resistance to the Indonesian occupation was developed on three fronts: a military front, a clandestine front and a diplomatic front (Cabral \& Martin-Jones, 
2008). The Timorese in exile (principally in Portugal, Australia and Mozambique) developed the diplomatic front, building lines of communication with the United Nations (UN), with national governments and with non-governmental organisations (NGOs) supporting the East Timorese Resistance. Significant diplomatic support came from the former Portuguese colonies in Africa, the PALOP countries (Paíes Africanos de Língua Oficial Portuguesa - African Countries with Portuguese as an Official Language).

The official language of the Resistance was Portuguese. It was employed on the diplomatic front, along with English. On the military and clandestine fronts, Tetum was most widely used, in spoken and written form, due to the diverse backgrounds of those involved (Cabral \& Martin-Jones, 2008). A new order of indexicality was created through the political, ideological and discursive practices of the East Timorese Resistance. Portuguese was being redefined in opposition to Indonesian, the language of the occupying power. At the same time, Tetum gained new status as a unifying language and as a language of solidarity.

In the mid-1990s, there was a political crisis in Indonesia, in the wake of the collapse of the economy. Indonesians could no longer carry the financial burden of sustaining a significant military presence in the eastern region of Timor. A change of leadership followed persistent protests in Jakarta, B.J. Habibie replaced Suharto as President. This opened up a window for diplomacy. Habibie agreed to a UNsponsored referendum on the future of the territory. A historic vote in favour of independence was made by the East Timorese people on August 30, 1999 (Martin, 2001). Indonesian troops were obliged to withdraw, though they unleashed considerable violence as they did so, using local militias. UN troops moved in and shortly thereafter, a UN administration (UNTAET) was set up from 1999 to 2002, with a view to preparing the ground for independence.

\section{A new nation developing language policy in a global age: The political and discursive challenges for Timor-Leste}

As Cabral (2013: 88) points out: "In the early 1990s, the leadership of the East Timorese Resistance was already preparing the ground for Independence". A national front, including different political parties, individuals from civil society and the Catholic Church was formally constituted in 1998 as the Conselho Nacional da Resistência Timorense (CNRT - The National Council for the Timorese Resistance). The details of the future language policy of the nation of Timor-Leste were debated within this forum. According to Cabral (2013), there was a broad consensus around the choice of Portuguese and Tetum as the two co-official languages. During the three years of the UN Administration, a Constituent Assembly 
was established, and this Assembly appointed a Commission to review the draft Constitution, including the provisions regarding language policy. The final text of the Constitution was approved by the Constituent Assembly in February 2002. The terms of the Constitution, which dealt with the status of different languages were as follows:

- Portuguese and Tetum were adopted as co-official languages

- All other languages were defined as national languages which were to be protected and valued by the state.

- Tetum was also defined as a national language

- English and Indonesian were given the status of working languages

(Constituent Assembly, 2002, Constitution of the Democratic Republic of Timor-Leste, Section 13, p. 16)

The adoption of Indonesian as a working language indexed the complexity of making the transition away from the political, social and linguistic regime imposed during the Indonesian occupation. The adoption of English indexed the new presence of international development actors, such as UN agencies, the World Bank and NGOs operating internationally.

The Democratic Republic of Timor-Leste finally came into being on May 20, 2002, with a FRETILIN-led government. The terms of the Constitution guided the development of language-in-education policy and practice from then onwards. In the period immediately after independence, the focus was primarily on the replacement of Indonesian by Portuguese as the medium of instruction in the schools. The implementation of this first phase of language-in-education policy development was supported through bilateral agreements with Portugal, and later with Brazil (Nicolai, 2004). In 2003, the Ministry of Education began work on a new curriculum for primary education. The design and implementation of this curriculum was also undertaken with donor assistance. The primary funding came from UNICEF and the curriculum was designed in collaboration with educationalists from a Portuguese university (Shah, 2012).

Once it was put in place, in-service teacher education included Portuguese language courses, as well as specialised in-service provision relating to teaching and learning in different areas of the curriculum through the medium of Portuguese. There were different institutional providers for this in-service education, from Portugal, Brazil, UNICEF and some international NGOs. However, according to Shah (2011: 76) concerns were expressed in relation to "the lack of coordination between training providers".

In 2004, a standardised orthography for Tetum was developed by the Instituto Nacional de Linguística (INL - National Institute for Linguistics). This orthography 
was formally adopted by governmental decree. Reviewing the terms of this decree, Taylor-Leech (2009) observed that, in addition to promotion of the new orthography, it emphasised the status of Tetum and its role in nation-building. This policy document stated that:

Tetum, given it dual status as an official and national language, must be used in a consistent manner in the entire administration of the State [and in other institutions] as well as by the mass media. Tetum is an essential element in the construction of the Nation and in the affirmation of East-Timorese identity (cited in Taylor-Leech, 2009: 44)

Despite the positive affirmation of the status and role of Tetum in policy statements such as this, there has continued to be considerable discursive ambivalence among those overseeing the development of education policy and practice. Take, for instance, the contrasting statements about Tetum that appeared in a new curriculum framework for primary education (2004-2009) that was introduced in Grades 1 and 2 in 2005, by the Ministry of Education, Culture, Youth and Sport (MECYS). In one section of this policy document, it was stated that: "Portuguese and Tetum are the languages of instruction" (MECYS, 2004: 8) and that the curriculum objectives included "the development of the two languages at the same time in a process of mutual enrichment" (MECYS, 2004: 9). However, a different view of the role of Tetum is articulated in another part of the same document. In the extract below, Tetum is characterised as a "pedagogic aide", to be used alongside Portuguese in some curriculum areas:

Since Tetum is at a preliminary stage of development, the implementation of Portuguese will have precedence, and Tetum may be used as a pedagogic aide in the teaching of disciplines related to the environment, social sciences, history and geography

(MECYS, 2004: 11)

In 2007, general elections ushered in a new coalition government. In 2008, the new Ministry of Education (MoE) provided clearer guidance on the use of Portuguese and Tetum in the first cycle of primary education (Grades 1-4). This new policy document (MoE, 2008) specified as follows the proportion of time that should be devoted to the use of Tetum and Portuguese at each of the four grade levels, following a transitional bilingual education model:

Grade 1:Tetum, 70 per cent; Portuguese, 30 per cent Grade 2:Tetum, 50 per cent; Portuguese, 50 per cent Grade 3:Tetum, 50 per cent; Portuguese, 50 per cent Grade 4:Tetum, 50 per cent; Portuguese, 50 per cent

Reference was also made to language in other policy documents and in legislation introduced in 2008. One of the objectives of new legislation regarding basic 
education was to "ensure mastery of Portuguese and Tetum" (Article 12d, MoE 2008: 8). And, in a National Education Strategic Plan (NESP) for 2011-2015, language education was explicitly tied to nation-building in the following terms: "our new national curriculum will teach our children about our national values, history, and culture promoting fluency in our two official languages" (Taylor-Leech, 2011: 10).

The status assigned to Portuguese and to Tetum in post-independence language policy-making needs to be understood with reference to the role played by these two languages, in opposition to Indonesian, during the years of the Timorese opposition to the Indonesian occupation. Tetum was established as the main language of wider communication during this period and the significance of Portuguese was redefined through its official use by the Resistance.

However, if we move beyond the national scale, and if we consider the wider global scenario, we see the need to take account of wider political, economic and cultural developments that have a direct bearing on current discourses about Portuguese on the national scale. 1996 saw the formation of the Comunidade dos Países da Língua Portuguesa (CPLP - Community of Portuguese Language Countries) by the Heads of Government of Angola, Brazil, Cape Verde, Guinea Bissau, Portugal, Mozambique and São Tomé e Príncipe. As stated on the CPLP web site, this body has three main objectives:

1. To facilitate political ties between member states in order to reinforce their presence on the international stage;

2. To collaborate in all domains, including education, health sciences, technology, defence, agriculture, public administration, communications, justice, public security, culture, sports and social communication.

3. To promote the Portuguese language $<$ http://www.cplp.org $>$.

On independence in 2002, Timor-Leste joined the CPLP. Given Timor-Leste's current positioning (or 'placement') on the periphery of the current global economic order, membership of the CPLP and investment in the Portuguese language offers new political, economic, cultural and educational opportunities, alongside the building of new postcolonial relations with Portugal. As part of its new commitment to this international bloc, Timor-Leste acted as host for the conference of the Heads of States involved in the CPLP in December 2014. CPLP has now established an office in Dili.

The current political, social and cultural order in Timor-Leste, and the discourses and language ideologies that are taking shape within it, are quite different from the political and sociolinguistic regimes that have been imposed in the past, by distant centres of power. Timor-Leste remains on the periphery of the 
global political and economic order, but it is now in a position to develop its own language-in-education policy. However, in the multipolar world of the twenty first century, the implementation of language policy decisions involves diverse political and institutional actors, from other nations, from UN bodies and from nongovernmental organisations operating internationally, with different discourses about language. Moreover, with contemporary mobilities, people, texts and material resources from diverse centers are increasingly moving into the periphery. Thus, we see Portuguese and Brazilian educators and language specialists running teacher education programmes for East-Timorese teachers. We also see textbooks and teaching materials, produced in Portuguese, in Portugal, being used in classrooms across the country. On the local scale, teachers find themselves having to develop discursive strategies for implementing language policy provisions in the daily rounds of interactional life in their classrooms and, as we will show below, they have to act as the mediators of texts and curriculum materials that have been produced elsewhere.

We turn now to the study conducted by Ildegrada Da Costa Cabral. In the remainder of the article, our aim is to cast some light on the situated ways in which the complex center-periphery dynamics of today's world are playing out on different scales of language policy-making at the heart of this new nation. We will illustrate some of the discourses articulated by social actors positioned on the national scale and some of the translingual and textual practices observed on the scale of the classroom. We begin, in the section below, with a brief sketch of the way in which the study was designed and conducted.

\section{A linguistic ethnographic study in Timor-Leste}

This study was designed as a multi-scalar and multi-sited ethnography of language policy processes at work in different institutional settings. Following the tradition of research on linguistic ethnography (Copland \& Creese, 2015; Snell et al., 2015), participant observation and interviews were combined with analysis of talk-ininteraction. As Snell et al. (2015: 8-9) have put it: "For ethnographers, the combination with linguistics presents an opportunity to hone in on specific instances of everyday life and to evidence analysis in small instances of social practice".

Six of the interviews in the study were conducted with elite social actors who were closely involved in language-in-education policy-making on the national scale. These interviews were conducted in different sites, at the national university, at the Parliament and at the Ministry of Education.

The other research site for this study was a Catholic primary school in Dili. The school was financially supported by institutions and companies based in 
Portugal and it had about 700 students in 2012. The reason for opening this school after independence was to cater for the large number of East-Timorese families seeking education in Portuguese for their children; and thus an emphasis was placed on the use of Portuguese as the medium of instruction. At the same time, the overall director of the school did not disregard Tetum. He described it as being a valuable symbolic resource.

Observations were conducted in two classrooms over a period of two months, with two different teachers, Teacher Dalia and Teacher Lucia. ${ }^{1}$ Teacher-student interactions were audio-recorded, transcribed and analysed. Interviews were also conducted with the director of the school and with the two teachers. Through the interviews with the teachers, and informal conversations with them, insights were gleaned into their own lived experiences of language-in-education and their personal trajectories during the years of the Indonesian occupation.

\section{Policy discourses: National and global perspectives}

In this section, we focus on extracts from the interviews conducted with two of the elite social actors participating in the study. Both had supported the Resistance and had been closely involved in the original process of language policy creation. The fictitious names of these two participants are Tomás Mota and Daniel Santos. The interview with Mr. Mota was conducted in Tetum and with Dr. Santos in Portuguese. Both interviews have been translated into English. In 2012, at the time of the interview, Mr. Mota held a senior position at the Ministry of Education. Since independence Dr. Santos has been appointed to a number of high-ranking academic positions. He also serves as a political advisor.

The questions for the interviews were designed to be open-ended in order to elicit the interviewees' personal views on language-in-education policy in Timor-Leste and to let them to say as much as they felt necessary about each topic. Extracts of official policy documents were selected and the two interviewees were asked to comment on them. The first question about the policy documents was based on an extract from the Constitution: "Tetum and Portuguese shall be the official languages in the Democratic Republic of Timor-Leste", Section 13) (“Tétum e Português serão as línguas oficiais da República Democrática de Timor-Leste", Secção 13). They were asked if they agreed with this statement.

1. All names in this article are fictitious names so as to ensure the anonymity of research participants. 
In his answer to this question, Mr. Mota referred to a course he had taken in Singapore. He said that the topic he had chosen to write about was the language policy of Timor-Leste. He had also been asked to present his work to his colleagues on the course. After his presentation, he had been asked to explain the reasons for selecting Portuguese as one of the official languages, and for not selecting English or Indonesian. Extract 1 shows his account of the response he gave in that context:

\section{Extract 1. From the interview with Mr. Tomás Mota (04/05/2012)}

We have chosen Portuguese, and I was involved, inside the Resistance, I see that there are three aspects. One to be seen in political terms, one in geographical terms, and a third one in historical terms. In political terms, Timor-Leste is nowadays a country, [inaudible] a state with its own rights and, as such, it decides what languages should be used. In geographical terms, as you have said earlier, we are a small island, half of an island. There are two countries that tower over us: Australia and Indonesia. Indonesia... I can say that it is like an animal, an elephant, a mild one, but a big animal. The nation of Australia is [also] like an animal, a wild one, but aggressive, I could even compare it to a small lion, maybe an aggressive, angry one, because it is an industrial nation, a developed nation. Indonesia, even after 50, 60 or 70 years of independence and development, is still slow and it is not a major threat to Timor. But in terms of community, in terms of population, it is a major threat to Timor. Australia is also a major and direct threat. So if we had chosen English [or Indonesian] then, in geographical terms, we would not have needed to build a border, a large border, or a Berlin wall between the west and the east of Timor. But language is like, Portuguese is like a border for the Timorese people. And history yes, there were 450 years of occupation...but history writes that Timor was a Portuguese colony. This connection is very strong and nowadays, after independence, Timor is now an ex-colony of Portugal and has got its independence. The way to strengthen this friendship is by forming the CPLP, countries which speak Portuguese. Before Timor had achieved its independence or [rather] restored its independence, Timor-Leste was already involved in [the CPLP].

Mr. Mota's views on the language policy had clearly been shaped by his involvement with the Resistance. He drew on different metaphors as he oriented towards different centres in his discourse. In his references to Australia and Indonesia, his discourse evoked notions of menace and hostility with dramatic images of wild animals; whereas when referring to Portugal and the CPLP his discourse evoked cooperation and alliance between friends. The Portuguese language was represented as a border fence that separates and defends Timor-Leste from Australia and Indonesia. He also defined the use of Portuguese and involvement in CPLP as being closely bound up with nation building. 
This link with CPLP was made explicit in a language-in-education policy document signed by members of the Parliament in August 2011. The title of the document was "The importance of the promotion and teaching of the official languages for national unity and cohesion and for the consolidation of a unique and original identity in the world"2. Mr. Mota and Dr. Santos were also asked to comment on an extract from this policy document. The extract was worded as follows: "Language policy in Timor-Leste is a means to access and to contribute to general knowledge, but it is also a privileged means to reinforce national unity and cohesion by allowing a tranquil communication between the parts that constitute the whole nation, and the interaction with people historically linked within the Community of Portuguese Language Countries." (p. 1). Extract 2 shows how Mr. Mota spoke of his interpretation of this extract.

\section{Extract 2. From the same interview with Mr. Tomás Mota (04/05/2012)}

That is what I said before about CPLP, when we know Portuguese, then we will have older brothers from Portugal, Angola, from Brazil, from Mozambique and from Guinea-Bissau. That is why Timor-Leste became a member of the CPLP (...) first as a means to strengthen the bond of friendship, our (..) historical relationship in which we were all Portuguese colonies. (...) In political terms to strengthen our relationship with the [other] member countries of the CPLP, if a threat arises in one of the nations then, because we are friends, (...) support is given, as happened in the past, during the 2006 crisis when GNR forces ${ }^{3}$ arrived within 24 hours at the airport in Baucau. This was no longer a colonial force, but like an older brother [Portugal], helping a younger one, and then Brazil also followed. This is what I mean by political terms. These are my own views.

In this and the previous extract, we see that Mr. Mota clearly valued Portuguese as a means of forging closer ties with CPLP members, notably the most powerful political actors at the centre of the CPLP, namely Portugal and Brazil. The political ties with these nation-states were described using kinship metaphors, echoing a new discourse of 'brotherhood' with Timor-Leste that emerged from 1999 onwards (Vale de Almeida, 2001).

Mr. Mota also made reference to different time-scales as he talked about the value of Portuguese. He referred to the experience of colonialism shared with the PALOP countries. He also talked about events in Timor-Leste in the recent past,

2. This is our translation for the title of the document in Portuguese: "A importância da promoção e do ensino das línguas oficiais para a unidade e coesão nacionais e para a consolidação de uma identidade própria e original no mundo"

3. GNR stands for Guarda Nacional Republicana (National Republican Guard). These are the special police forces in Portugal. 
in 2006, associated with a political challenge to the first FRETILIN-led government. He recalled the arrival of the Portuguese special police force (GNR) and their actions in restoring order in a moment of political crisis. He expressed the view that the Portuguese police "was no longer a colonial force". Anticipating the future, he also saw Portuguese as being a means of forging new political relations with the nations within the CPLP.

Extract 3 below shows part of a response by Dr. Santos to the same interview question related to CPLP. Dr. Santos' words were as follows:

\section{Extract 3. Interview with Dr. Daniel Santos (05/06/2012)}

It is within that context, within that spirit of CPLP, that I think that the government overseeing our sovereignty wants to defend Portuguese: It is not only to reclaim our history, and the colonial past, it is also for the advantages that this choice guarantees, of an intercontinental connection. This [decision was made] to honour the support, the solidarity of the past for the success of our struggle because all the continents were involved, but also to express a desire to participate actively in the development of transnational communication, in a cultural interaction between people and in various continents, in all continents, simultaneously. We are little, but we are included in a bloc which could echo our interests at any time and we could be listened to in any part of the world. This was one of the factors, I think, behind the success of our Resistance and it could continue to be an important factor, for the challenges that we want to address, and for what we want to defend for the future.

Dr. Santos referred to three different time-scales, two in the past and one in the future: (1) the years of Portuguese colonial rule; (2) the 24 years of Indonesian occupation and resistance to it, with the support of the former Portuguese colonies in Africa that became independent in 1975; and (3) the future of Timor-Leste, which he saw as being oriented to participation in the CPLP. From his point of view, in espousing Portuguese as one of the official languages, the government of Timor-Leste was taking account of the role and significance of Portuguese during the years of the Resistance, rather than its role in the distant colonial past. The designation of the Portuguese language as one of the official languages of the nation was also, for him, a means of acknowledging the support provided to the EastTimorese Resistance by the PALOP nations and by NGOs in Portugal and Brazil. In addition, Portuguese represented a form of symbolic capital which could provide access for Timor-Leste to an increasingly significant new grouping of nationstates in the world.

In the policy-related discourse of both Dr Santos and Mr Mota, Portuguese was clearly represented as being a valuable resource for building political alliances within the contemporary global order. A narrative about transnational bonds based on 'brotherhood,' 'friendship' and solidarity predominated in these 
interviews and in the other interviews conducted in this study. An older narrative about the symbolic domination and inequities created by years of colonisation by Portugal was less visible in their accounts. National narratives about the relationship between the periphery and different centers in a globalised world are often shaped by the individual narratives produced and reproduced by elite social actors like these two participants.

Next we will turn to language policy processes at work on a different scale. We take a look at translingual and textual practices observed in a Year 6 classroom and we describe the ways in which teachers and pupils were making meaning around a Portuguese textbook. We also show how the textbook made references to another peripheral nation within the CPLP.

\section{The Year 6 classroom and teacher Dalia}

The Year 6 classroom had 46 pupils, 21 boys and 25 girls. They were 12 and 13 years old. According to the head teacher, many parents of the children who attended this school worked as civil servants in Dili. The textbooks used in this classroom were all written in Portuguese.

Teacher Dalia was the Portuguese language teacher (Língua Portuguesa). She had been teaching in the school since 1998. She had been invited to join the staff due to her knowledge of Portuguese. Initially, she had received some training from Portuguese teachers at the Escola Portuguesa (Portuguese School), and then she had attended a university course for teachers from 2005 to 2009 to upgrade her qualifications. During an interview with Ildegrada Da Costa Cabral, she said she had learnt Portuguese in a Catholic school up to Year 3. Her schooling had then been interrupted by the Indonesian invasion in 1975. She said she had no knowledge of Bahasa-Indonesia, and indicated that she used both Portuguese and Tetum at home and in the school with her colleagues.

In the section below we take a close look at a transcript of an episode of classroom interaction in her class.

\section{Talk around the textbook: Linking different 'lusophone' worlds}

In Teacher Dalia’s classroom, lessons were largely accomplished by closely following the Portuguese textbook. Given her educational background in Portuguese and the school's preference for using mostly Portuguese, her lessons were mostly conducted in Portuguese. Moreover, the pupils were expected to perform certain rituals such as standing up to read aloud from the textbook or copying textbook 
extracts from the blackboard. These classroom routines indexed the authority given to textbooks as the main source of curriculum knowledge.

The textbook was entitled: 8 mundos, 8 vozes ( 8 worlds, 8 voices). The eight 'worlds' were the countries that were members of the CPLP at the time. The textbook had been created in 2008 in Lisbon by a team of textbook writers who included two Portuguese people and one East-Timorese. The team was coordinated by one of the Portuguese authors, Lúcia Vidal Soares, for a publisher in Portugal called LIDEL. There was a book of exercises as well as a textbook. The covers of the two books are shown in Figure 1 below.
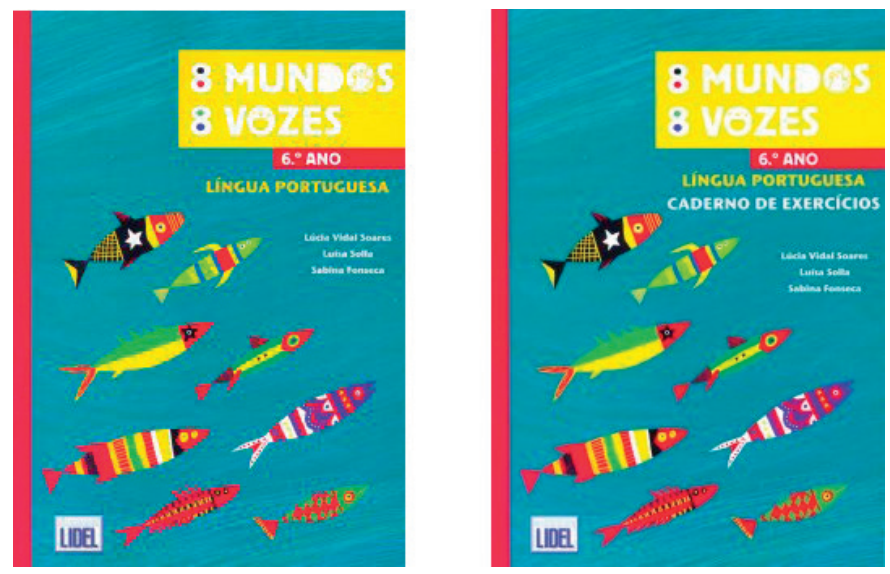

Figure 1. The cover of the textbook and of the book of exercises

Luke (1988) points out that textbooks are resources for ideological incorporation through which sets of ideas, attitudes, values and competences are transmitted. This observation is highly relevant to the textbook in question, both in terms of its presentation (i.e. the cover) and in terms of the content. The cover was brightly coloured with pictures of fishes on a blue background. Each of the fishes was decorated with the flag of one the nation-states that were members of CPLP at the time when the books were produced: According to Vidal Soares (2011), the coordinator of the project, the textbook represents a 'journey' through each of these nations.

Da Costa Cabral (2015) observed lessons which focused on texts in this textbook relating to different CPLP nations: Angola and São Tomé e Príncipe. The text we focus on here draws on a legend about roosters from São Tomé e Príncipe. For this article, we will focus on the classroom conversation that unfolded around this traditional story from São Tomé e Príncipe.

The title of the text was: "A lenda do canta-galos" (The legend of the roostersingers). This legend was about a mythical place in São Tomé e Príncipe which 
served as a shelter for all the roosters in the world. These roosters sang in chorus every day, early in the morning, but also every time that they wanted to. However, there was a large group of residents nearby who felt disturbed by this noise and started complaining. Arguments started between the residents who were in favour of the roosters and those who were against. Finally, one man told the roosters to move out in 24 hours or a war would be declared. The roosters decided to leave the place, they elected their own leader and, after some time, they found another place and stayed there forever. People called the place "Cantagalo" (Rooster-singer).

When she introduced this text to her class, Teacher Dalia first asked pupils to read different parts of the text, row by row, in chorus, and then she started posing questions about the text. The interactional sequence is shown in Extract 4 below. See Appendix for transcription conventions.

\section{Extract 4.}

\begin{tabular}{|c|c|c|c|}
\hline \multicolumn{2}{|l|}{ Line } & \multirow{2}{*}{$\begin{array}{l}\text { Original languages used } \\
\text { galo né, sabe as horas dele. quais as } \\
\text { horas }\end{array}$} & \multirow{2}{*}{$\begin{array}{l}\text { Translation into English } \\
\text { this rooster, knows his time, what } \\
\text { times }\end{array}$} \\
\hline 81 & TD & & \\
\hline 82 & & que ele pode $/ 2 /$ cantar, sabe as horas & he can sing /2/ sing, he knows his times, \\
\hline 83 & & dele, onde é que estes galos, há muitos, & where these roosters took refuge a, long \\
\hline 84 & & muitos anos, todos os galos do mundo & time ago, many many years ago, all the \\
\hline 85 & & refugiam-se para a ilha de são tomé & $\begin{array}{l}\text { roosters of the world on the island of } \\
\text { são }\end{array}$ \\
\hline \multirow[t]{3}{*}{86} & & $\begin{array}{l}\text { quer dizer que, todos os galos do } \\
\text { mundo }\end{array}$ & tomé \\
\hline & & para onde é que foram? /2/ & what I mean is, all the roosters of the \\
\hline & & & world where did they go? /2/ \\
\hline 87 & PPS & $\begin{array}{l}\text { ilha de são tomé [a few pupils replied } \\
\text { in chorus] }\end{array}$ & $\begin{array}{l}\text { island of são tomé [a few pupils replied } \\
\text { in chorus] }\end{array}$ \\
\hline 88 & $\mathrm{TD}$ & ilha de são tomé & onde é fica são tomé? onde? \\
\hline 89 & & onde é fica são tomé? onde? & where is são tomé? where? \\
\hline 90 & MP & Espanhol & spanish \\
\hline 91 & TD & hã? & hum? \\
\hline 92 & MP & espanhol [same boy] & spanish [same boy] \\
\hline 93 & $\mathrm{TD}$ & onde? & where? \\
\hline 94 & MP & Brasil & brazil \\
\hline 95 & & [inaudible] & [inaudible] \\
\hline 96 & MP & Portugal & Portugal \\
\hline 97 & PPS & $\begin{array}{l}\text { europa [alternative responses from } 2 \text { or } \\
3 \text { pupils] }\end{array}$ & $\begin{array}{l}\text { europa [alternative responses from } 2 \text { or } \\
3 \text { pupils] }\end{array}$ \\
\hline
\end{tabular}


Extract 4. (Continued)

\begin{tabular}{|c|c|c|c|}
\hline \multicolumn{2}{|c|}{ Line } & \multirow{2}{*}{$\begin{array}{l}\text { Original languages used } \\
\text { Brasilía }\end{array}$} & \multirow{2}{*}{$\begin{array}{l}\text { Translation into English } \\
\text { Brasilía }\end{array}$} \\
\hline 98 & $\mathrm{PP}$ & & \\
\hline 99 & FP & Europa & europa \\
\hline 100 & TD & a ilha de são tomé? ilha quer dizer, ilha & the island of são tomé? island means, \\
\hline 101 & & $\begin{array}{l}\text { quer dizer um pedaço de terra } \\
\text { cercada de }\end{array}$ & $\begin{array}{l}\text { island means a piece of land } \\
\text { surrounded }\end{array}$ \\
\hline & & água por todos os /2/ & by water in all its $/ 2 /$ \\
\hline 102 & MP & Ilha & island \\
\hline 103 & TD & $\begin{array}{l}\text { lados, como timor, timor é uma ilha, } \\
\text { é um }\end{array}$ & $\begin{array}{l}\text { sides, like timor, timor is an island, it } \\
\text { is a }\end{array}$ \\
\hline 104 & & $\begin{array}{l}\text { pedaço de terra, mas ao redor desta } \\
\text { terra, }\end{array}$ & piece of land, but around this land, \\
\hline 105 & & à volta dele o que está cercada? /2/ & around it what is there? /2/ \\
\hline 106 & $\mathrm{PP}$ & $\begin{array}{l}\text { água [said by one pupil in a low and } \\
\text { shy voice] }\end{array}$ & $\begin{array}{l}\text { water [said by one pupil in a low and } \\
\text { shy voice] }\end{array}$ \\
\hline 107 & $\mathrm{PP}$ & $\begin{array}{l}\text { mar [said by one pupil in a low and shy } \\
\text { voice] }\end{array}$ & $\begin{array}{l}\text { sea [said by one pupil in a low and shy } \\
\text { voice] }\end{array}$ \\
\hline 108 & $\mathrm{TD}$ & de quê? & of what? \\
\hline 109 & $\mathrm{PP}$ & $\begin{array}{l}\text { água [said one pupil in lower and shy } \\
\text { voice] }\end{array}$ & $\begin{array}{l}\text { water [said one pupil in lower and shy } \\
\text { voice] }\end{array}$ \\
\hline 110 & $\mathrm{PP}$ & $\begin{array}{l}\text { mar [said one pupil in lower and shy } \\
\text { voice] }\end{array}$ & $\begin{array}{l}\text { sea [said one pupil in lower and shy } \\
\text { voice] }\end{array}$ \\
\hline 111 & TD & MAR & SEA \\
\hline 112 & & $\begin{array}{l}\text { timor né rai ida maibé ninian volta } \\
\text { haleu }\end{array}$ & $\begin{array}{l}\text { timor is a piece of land but it has } \\
\text { around }\end{array}$ \\
\hline 113 & & né se maka haleu? & it what? what is around it? \\
\hline 114 & PPS & $\begin{array}{l}\text { TACI [many pupils responding loudly } \\
\text { and in chorus] }\end{array}$ & $\begin{array}{l}\text { SEA [many pupils responding loudly } \\
\text { and in chorus] }\end{array}$ \\
\hline 115 & TD & taci maka haleu nian & the sea surrounds it \\
\hline 116 & & então a ilha de timor é uma? & so the island of timor is an? \\
\hline 117 & PPS & $\begin{array}{l}\text { ilha [many pupils responding loudly } \\
\text { and in chorus] }\end{array}$ & $\begin{array}{l}\text { island [many pupils responding loudly } \\
\text { and in chorus] }\end{array}$ \\
\hline
\end{tabular}

(Audio-recorded 28/05/2012)

Teacher Dalia first checked if everybody had understood the text. She then asked about the meaning of the title of the text: what the word 'lenda' (legend) and 'cantagalo' (rooster-singer) meant. Next, in lines 88-89, she asked where São Tomé e Príncipe was. In response, the pupils started rapidly naming places they had heard of such as Spain, Brazil, Portugal, Europe, or even Brasilia, using 
place names and adjectives. It was clear that they did not know where São Tomé e Príncipe was.

However, the teacher did not provide the answer about the geographical location of São Tomé e Príncipe at this point in the lesson. Instead, in lines 100-101, she shifted the topic to the fact that São Tomé e Príncipe is an island and explained the meaning of 'island'. The strategy she used was to illustrate the notion of 'island' with reference to Timor, emphasising the fact that it was surrounded by sea. She then switched to Tetum in lines $112-113$ to ensure that all students had understood the words mar (sea) and ilha (island). Finally, she got them to answer in chorus in Portuguese in line 117, to demonstrate that they knew how to say ilha (island).

She returned to the topic of the location of São Tomé e Príncipe later on in the episode as shown in Extract 5 below. When she turned to Ildegrada Da Costa Cabral, in line 695, to ask for guidance, it became clear that she herself was unsure about its location. Once she had received confirmation that São Tomé e Príncipe was in Africa (lines 701-702), she was able to counter the claims made by some of the pupils that it was in Europe.

\section{Extract 5.}

\begin{tabular}{llll}
\hline Line & & Original languages used & Translation into English \\
\hline 693 & TD & são tomé é uma ilha & são tomé is an Island \\
694 & & $\begin{array}{l}\text { uma ilha na } \\
\text { professora, é uma ilha do? }\end{array}$ & $\begin{array}{l}\text { an island in } \\
\text { teacher, it is an island in? } \\
695\end{array}$ \\
& & Europeia & europe \\
696 & PP & Europa & europe \\
697 & PP & áfrica [speaking in a low voice] & africa [speaking in a low voice] \\
698 & I & áfrica? África & africa? africa \\
699 & TD & Europa & europe \\
700 & PP & é uma ilha que está na áfrica & it is an Island in africa \\
701 & TD & não é na Europa & it is not in Europe \\
702 & &
\end{tabular}

(Audio-recorded 28/05/2012)

When asked about this switch into Tetum, and other switches observed during the longer classroom episode, Teacher Dalia indicated that she used Tetum to accommodate the pupils' needs, saying "we have to use Tetum otherwise they won't understand". In fact, her recurring practice of switching into Tetum was clearly familiar to the pupils. They already knew that if she asked a question in Tetum then they should respond in Tetum, as in line 114. 
At the scale of this local classroom, we can see, up close and in detail, how the teacher was managing the language policy that had been defined at the national scale. We can also see how she mediated the content of the textbook for the pupils, making connections between the world of the text and their local worlds. To do this she used both Portuguese and Tetum, with Portuguese being the language that was used and valued most in her classroom. Yet, because lessons could not be accomplished only in Portuguese, she used Tetum as well. However, she was constrained by her lack of knowledge about the 'lusophone' world and about São Tomé e Príncipe in particular. She also had little time to prepare her lessons. So her solution, in this particular teaching/learning exchange, was to focus on the fact that both CPLP nations were located on islands. She relied on the presence of Ildegrada Da Costa Cabral in her class to be able to provide a definitive answer to the pupils about the location of the African island nation. She expected her to know the answer as she was aware that she had received training in Portugal as a primary school teacher.

The textbook used by teacher Dalia contributed to the wider national policy goal of transmitting knowledge about the 'lusophone world' and building connections between East-Timorese citizens and citizens of the nation-states within the CPLP. Teacher Dalia oriented her lessons towards the language policy and the textbook served as her main link to the 'lusophone' world. However, she had little daily contact with this world and scant knowledge of it. She knew more about the pupils' everyday lives in Dili. In contrast, the two policymakers introduced above had interacted quite often with other social actors within this 'lusophone' world, in Timor-Leste and abroad, due to their higher status within the political scene.

\section{Concluding remarks}

As we have shown in this article, different regimes of language were imposed in the past in the eastern region of the island of Timor, in the context of different center-periphery relations: first, by the Portuguese colonialists, and then by the Indonesian occupying power, with its center in Java. However, in the context of the Indonesian occupation, the symbolic value of Portuguese came to be redefined through its use as the official language of the East-Timorese Resistance. Tetum was also widely used within the Resistance and became an emblem of solidarity and Timoreseness. This new order of indexicality, forged within the Resistance, became the main basis for Timor-Leste's agentive language policy move to adopt Portuguese and Tetum as co-official languages of the new nation on independence. This move by the leadership in Timor-Leste 
in 2002 had been widely debated prior to independence and a broad consensus had been established.

At the same time, the adoption of Portuguese as one of the official languages oriented the new nation to a particular set of international relations and political ties (in addition to the existing geopolitical relations in the region) and to new and more complex center-periphery relations. It was an orientation to the 'lusophone world', embodied in the CPLP, with Portugal and Brazil as key players, but ties were also retained with the PALOP nations which had provided crucial diplomatic support during the years of the Resistance. So, in the interviews with two elite social actors cited in this article, we see references to Portugal, Brazil and the PALOP nations being made with metaphors of "friendship" and even "kinship" (e.g. with all these nations being referred to as "older brothers").

As we have also shown in this article, this national language policy move has had particular consequences for language-in-education policy making and these consequences have been felt on different scales: language policy implementation on the national scale, including teacher education, curriculum development and the development of teaching/learning resources, has been supported through bilateral agreements with the Portuguese and Brazilian governments, as well as UN bodies, and has involved diverse institutional actors and programmes. Language policy implementation on the scale of local schools and classrooms has been largely a matter for local educational practitioners, who have had differing degrees of access to in-service education and support.

Current support for the Portuguese language comes in the form of material resources, such as textbooks and programmes for the professional development of teachers. This support flows from the center to the periphery, adding further value to the language. The textbooks are produced in Portugal and incorporate a new vision of the world of Portuguese learners. Within this new language-in-education scenario, teachers are positioned as mediators of texts produced in the center. They mediate these texts and navigate the national language-in-education policy with the communicative resources available to them and their students, intertwining Tetum and Portuguese in their day to day interactions and using multimodal resources. In contrast, there are few resources available for the development of Tetum. Moreover, there is still some discursive ambivalence about its role in education. In the discourse of policy documents and in day to day interactional practices in classroom, Tetum - a language of the periphery - is being constructed as a 'pedagogic aide' (one imbued with Timorese-ness) in an education system where Portuguese is regarded as the most prestigious symbolic resource.

Following recent trends in language policy research, we have drawn on ethnographic and textual data gathered with research participants who are positioned 
on different scales. We have also argued that attention needs to be paid to: (1) the dynamics and consequences of center-periphery relations over longue durée; (2) the emergence of new discourses about language, and (3) the ways in which language-in-education policy-making is bound up with these developments. Our particular research lens has been tuned to recent developments in Timor-Leste, but a similar lens could be applied to the study of language policy processes at work in other nations on the global periphery.

\section{Acknowledgements}

We would like to acknowledge the valuable comments provided by the anonymous reviewers and by Dr Estêvão Cabral.

\section{References}

Blommaert, J. (2007). Sociolinguistic scales. Intercultural Pragmatics, 4(1), 1-19. doi:10.1515/IP.2007.001

Cabral, E. (2013). The development of language policy in global age: The case of East-Timor. In J. A. Shoba \& F. Chimbutane (Eds.), Bilingual education and language policy in the global south (pp. 83-103). London: Routledge.

Cabral, E., \& Martin-Jones, M. (2008). Writing the resistance: Literacy in East-Timor 1975-1999. International Journal of Bilingual Education and Bilingualism, 11(2), 149-169. doi: $10.2167 /$ beb491.0

Constituent Assembly. (2002). Constitution of the Democratic Republic of Timor-Leste (Section 13). Dili: Timor-Leste.

Copland, F., \& Creese, A., with F. Rock \& S. Shaw. (2015). Linguistic ethnography. London: Sage.

Da Costa Cabral, I. (2015). Multilingual talk, classroom textbooks and language values: A linguistic ethnographic study in Timor-Leste. Unpublished PhD dissertation, University of Birmingham, UK.

Errington, J. (1998). 'Indonesian development'. In B. Schiefflin, K. A. Woolard, \& P. V. Kroskrity (Eds.). Language ideologies: practice and theory (pp. 271-284). Oxford: Oxford University Press.

Franceschini, R. (2013). History of multilingualism. In C. Chapelle (Ed.), The encyclopedia of applied linguistics. Malden, MA: Wiley-Blackwell. doi:10.1002/9781405198431.Whealo511

Hajek, J. (2000). Language planning and the sociolinguistic environment in East Timor: Colonial practice and changing language ideologies. Current Issues in Language Planning, 1(3): 400-414. doi:10.1080/14664200008668014

Hajek, J. (2002). Language maintenance and survival in East-Timor: All change now? Winners and losers. In D. Bradley \& M. Bradley (Eds.), Language endangerment and language maintenance: An active approach. London: Curzon Press.

Hornberger, N. H., \& Johnson, D. C. (2007). Slicing the onion ethnographically: Layers and spaces in multilingual language education. TESOL Quarterly, 41(3), 509-532.

doi:10.1002/j.1545-7249.2007.tbooo83.x 
Hult, F. (2015). Making policy connections across scales using nexus analysis. In F. Hult \& D. C. Johnson (Eds.), Research methods in language policy and planning (pp. 217-231). Malden MA: John Wiley \& Sons.

Johnson, D. C. (2009). Ethnography of language policy. Language Policy, 8, 139-159. doi:10.1007/s10993-009-9136-9

Johnson, D. C. (2013). Language policy. Houndmills: Palgrave Macmillan. doi:10.1057/9781137316202

Lemos Pires, M. (1991). Descolonização de Timor: Missão Impossível? Lisboa: D. Quixote. Luke, A. (1988). Literacy, textbooks and ideology. London: Falmer Press.

MacQueen, N. (1997). The decolonisation of Portuguese Africa: Metropolitan revolution and the dissolution of empire. London: Longman.

Martin, I. (2001). Self-determination in East Timor: The United Nations, the ballot, and international intervention. London: Lynne Rienner.

Martin-Jones, M. \& Da Costa Cabral, I. (2018). The critical ethnographic turn in research on language policy and planning. In J. Tollefson \& M. Pérez-Milans (Eds.), The Oxford handbook of language policy and planning. Oxford: Oxford University Press.

McCarty, T. L. (Ed.). (2011). Ethnography of language policy. London: Routledge.

Ministry of Education (MoE). (2008). Education system framework law 14/2008 (Government of Timor-Leste). Dili, Timor-Leste: MoE.

Ministry of Education, Culture, Youth and Sport (MECYS). (2004). Education policy 2004-2009. Dili, Timor-Leste: MECYS.

Nicolai, S. (2004). Learning independence: Education in emergency and transition in East Timor since 1999. Paris: International Institute for Educational Planning.

Nixon, R. (2012). Justice and governance in East Timor: Indigenous approaches and the 'new subsistence state' (Routledge Contemporary Southeast Asia Series). New York: Routledge.

Pietikainen, S., Kelly Holmes, H., Jaffe, A., \& Coupland, N. (2016). Sociolinguistics from the periphery: Small languages in new circumstances. Cambridge: Cambridge University Press.

Shah, R. (2011). It takes two (or more) to tango: Partnerships within the education sector in Timor-Leste. International Education Journal: Comparative Perspectives, 10(2): 71-85.

Shah, R. (2012). Goodbye conflict, hello development? Curriculum reform in Timor-Leste International Journal of Educational Development, 32, 31-38. doi:10.1016/j.ijedudev.2011.04.005

Snell, J., Shaw, S., \& Copland, F. (Eds.). (2015). Linguistic ethnography: Interdisciplinary explorations. Houndmills: Palgrave Macmillan.

Taylor, J. G. (1999). East Timor: The price of freedom. New York, NY: Zed Books.

Taylor-Leech, K. (2009). The language situation in Timor-Leste. Current Issues in Language Planning, 10(1), 1-68. doi:10.1080/14664200802339840

Taylor-Leech, K. (2011). Timor-Leste: Sustaining and maintaining the national languages in education. Current Issues in Language Planning, 12(2), 289-308. doi:10.1080/14664208.2011.589108

Vale de Almeida, M. (2001). Epilogue of empire: East Timor and the Portuguese postcolonial catharsis. Identities, 8, 4.

Vale de Almeida, M. (2008). Anthropology and ethnography of the Portuguese-speaking empire. In P. Poddar, R. Patke, \& L. Jense (Eds.), A historical companion to postcolonial literatures. Continental Europe and its empires (pp. 435-439). Edinburgh: Edinburgh University Press. 
Vidal Soares, L. (2011). 'Qual é o papel da língua portuguesa na política educativa de TimorLeste?' In A. B. da Costa \& A. Barreto (Eds.), COOPEDU: Congresso Portugal e os PALOP Cooperação na Área da Educação. Lisbon: CEA, ISCTE-IUL.

\section{Web site consulted}

$<$ http://www.cplp.org/id-2595.aspx>

\section{Appendix Transcription conventions}

$\begin{array}{ll}\text { TD } & \text { Teacher Dalia } \\ \text { PPS } & \text { Pupils } \\ \text { PP } & \text { Pupil } \\ \text { FP } & \text { Female Pupil } \\ \text { MP } & \text { Male pupil } \\ \text { Plain font } & \text { in Portuguese } \\ \text { Bold } & \text { in Tetum } \\ \text { /2//10/ } & \text { Pause in seconds } \\ \text { [ ] } & \text { Researcher's comments } \\ \text { I } & \text { Ildegrada }\end{array}$

